\title{
A survey of peptidase activity in rumen bacteria
}

\author{
R. John Wallace* and Nest McKain
}

Rowett Research Institute, Bucksburn, Aberdeen AB2 9SB, UK

(Received 21 February 1991; revised 22 May 1991; accepted 29 May 1991)

\begin{abstract}
Twenty-nine strains of 14 species of rumen bacteria were screened for their ability to hydrolyse $\mathrm{Ala}_{2}, \mathrm{Ala}_{5}$, GlyArg-4-methoxy-2-naphthylamide (GlyArg-MNA) and Leu-MNA. Several species, notably Megasphaera elsdenii, were active against $\mathbf{A l a}_{2}$, and a smaller number, including Bacteroides ruminicola, Butyrivibrio fibrisolvens, Ruminococcus flavefaciens, Lachnospira multipara and Ruminobacter amylophilus, broke down Ala . Streptococcus bovis had an exceptionally high leucine arylamidase activity. However, only Ba. ruminicola hydrolysed GlyArg-MNA. Further investigation revealed that only Ba. ruminicola and Bu. fibrisolvens hydrolysed $\mathrm{Ala}_{5}$ to $\mathrm{Ala}_{3}$ and $\mathrm{Ala}_{2}$, with little $\mathrm{Ala}_{4}$ being produced, in a manner similar to rumen fluid. The activity of Ba. ruminicola against synthetic peptidase substrates, including GlyArg-MNA, LysAla-MNA, ArgArg-MNA, GlyPro-MNA, LeuVal-MNA, and Ala $\mathbf{a}_{3}-p$-nitroanilide, was similar to that of rumen fluid, whereas the activity of Bu. fibrisolvens was quite different. Since the main mechanism by which peptides are broken down in the rumen is similar to dipeptidyl aminopeptidase type I, for which GlyArg-MNA is a diagnostic substrate, it was concluded that $\mathrm{Ba}$. ruminicola was the most important single species in peptide breakdown in the rumen.
\end{abstract}

\section{Introduction}

The breakdown of peptides to amino acids by rumen micro-organisms is an integral part of the conversion of protein to ammonia, a process that often leads to the inefficient use of dietary protein by ruminants (Leng $\&$ Nolan, 1984). Various species of protozoa, bacteria and anaerobic fungi are responsible for proteolysis in rumen fluid (Wallace, 1988; Wallace \& Cotta, 1988), and the proteolytic population is highly variable (Wallace \& Cotta, 1988). The role of different microbial species in the conversion of peptides to amino acids has received less attention. Ciliate protozoa have a high specific activity against dipeptides, but this falls as peptide size increases, and bacteria are most important in hydrolysing peptides with three or more amino acid residues (Newbold et al., 1989; Wallace et al., 1990a,b).

Bladen et al. (1961) screened rumen contents for bacteria which produced ammonia from Trypticase, and found significant activity in $28 \%$ of isolates in a $72 \mathrm{~h}$ incubation. Half of these were Bacteroides ruminicola, while some strains of Butyrivibrio fibrisolvens, Megasphaera elsdenii and Selenomonas ruminantium were positive. Ammonia production from Trypticase could arise from amino acids rather than peptides, however, as

Abbreviations: HSA, heptane sulphonic acid; MNA, 4-methoxy-2naphthylamide; pNA, $p$-nitroanilide.
Trypticase contains some free amino acids. Furthermore, peptidolytic bacteria would also have to be able to deaminate amino acids in order to be identified from ammonia production. Thus, peptide hydrolysis was in some cases not necessary, and in others insufficient, for bacteria to have been picked out as peptidolytic in the study of Bladen et al. (1961).

Peptide hydrolysis in the rumen follows a distinctive pattern, characteristic of the peptides being broken down by a dipeptidyl aminopeptidase mechanism (Wallace \& McKain, 1989; Wallace et al., 1990a,b). In this study, rumen bacteria which carry out a similar peptidolytic hydrolysis were identified by screening a laboratory culture collection of predominant rumen bacteria. A preliminary report of some of this work has been published (Wallace et al., 1990b).

\section{Methods}

Rumen bacteria. The sources of the different strains used in this survey are listed in Table 1. Bacteria were grown in Hungate tubes (Bellco Glass) under $\mathrm{O}_{2}$-free $\mathrm{CO}_{2}$ at $39^{\circ} \mathrm{C}$ in Hobson's medium 2 (Hobson, 1969). Overnight cultures were recovered by centrifugation $(1100 \mathrm{~g}, 10 \mathrm{~min})$, washed once with $25 \mathrm{~mm}$-potassium phosphate buffer, $\mathrm{pH} 7.0$, made anaerobic by boiling and bubbling with $\mathrm{CO}_{2}$ and resuspended to half the original volume in the same buffer. 
Table 1. Peptidase activities of different species of rumen bacteria

Bacterial suspensions were incubated with substrates as described in Methods for periods up to $60 \mathrm{~min}$. The values given below are means of duplicate determinations on each of two cultures on separate days.

\begin{tabular}{|c|c|c|c|c|c|c|}
\hline \multirow[b]{2}{*}{ Species } & \multirow[b]{2}{*}{ Strain } & \multicolumn{4}{|c|}{$\begin{array}{c}\text { Peptidase activity } \\
{\left[\text { [nmol } \text { min }^{-1}(\text { mg protein })^{-1}\right]}\end{array}$} & \multirow[b]{2}{*}{ Source/reference } \\
\hline & & $\mathrm{Ala}_{2}$ & $\mathrm{Ala}_{5}$ & $\begin{array}{l}\text { GlyArg- } \\
\text { MNA }\end{array}$ & Leu-MNA & \\
\hline Anaerovibrio lipolytica & $5 S$ & 0 & 0 & 0 & 0 & ATCC 33276 \\
\hline \multirow{4}{*}{$\begin{array}{l}\text { Bacteroides ruminicola } \\
\text { subsp. ruminicola }\end{array}$} & $46 / 5$ & $2 \cdot 2$ & 0.5 & 0 & 0 & Flint \& Stewart (1987) \\
\hline & M384 & $3 \cdot 3$ & $2 \cdot 3$ & $10 \cdot 1$ & 0 & Wallace \& Brammall (1985) \\
\hline & $223 / \mathrm{M} 2 / 7$ & $12 \cdot 1$ & $11 \cdot 1$ & $5 \cdot 4$ & $0 \cdot 3$ & Flint \& Stewart (1987) \\
\hline & 2202 & $3 \cdot 2$ & $2 \cdot 1$ & $2 \cdot 5$ & 0 & NCFB 2202 \\
\hline \multirow[t]{2}{*}{ subsp. brevis } & F115 & $4 \cdot 5$ & $7 \cdot 5$ & 3.9 & 0 & Flint et al. (1988) \\
\hline & $118 \mathrm{~B}$ & $4 \cdot 0$ & $5 \cdot 5$ & $2 \cdot 5$ & 0 & NCFB 1935 \\
\hline \multirow[t]{2}{*}{ Butyrivibrio fibrisolvens } & JW11 & 0 & 0.6 & 0 & $0 \cdot 1$ & Wallace \& Brammall (1985) \\
\hline & SH13 & $1 \cdot 6$ & $4 \cdot 3$ & 0 & 0 & Wallace \& Brammall (1985) \\
\hline \multirow[t]{2}{*}{ Eubacterium ruminantium } & GA 195 & 1.6 & 1.0 & 0 & $0 \cdot 2$ & ATCC 17233 \\
\hline & $\mathrm{C} 2 / \mathrm{A} 164$ & $1 \cdot 1$ & $1 \cdot 2$ & 0 & 0 & Rowett Research Institute \\
\hline \multirow[t]{2}{*}{ Fibrobacter succinogenes } & S85 & $2 \cdot 4$ & $0 \cdot 2$ & $\mathbf{0}$ & 0 & ATCC 19169 \\
\hline & BL2 & $12 \cdot 7$ & $1 \cdot 4$ & 0 & 0 & NCFB 2576 \\
\hline \multirow[t]{2}{*}{ Lachnospira multipara } & D15d & 3.9 & $2 \cdot 9$ & 0 & 0 & $\begin{array}{l}\text { B.A. Dehority, Wooster, } \\
\text { Ohio, USA. }\end{array}$ \\
\hline & D32 & 3.9 & $2 \cdot 2$ & $\mathbf{0}$ & 0 & ATCC 19207 \\
\hline \multirow{2}{*}{ Megasphaera elsdenii } & $\mathrm{LCl}$ & $16 \cdot 5$ & $0 \cdot 2$ & 0 & 0 & NCFB 2264 \\
\hline & $\mathrm{J} \mathbf{1}$ & $14 \cdot 4$ & $0 \cdot 1$ & 0 & 0 & Rowett Research Institute \\
\hline \multirow[t]{2}{*}{ Ruminobacter amylophilus } & WP91 & 3.9 & $3 \cdot 3$ & $0 \cdot 3$ & $1 \cdot 1$ & NCFB 2234 \\
\hline & WP225 & $1 \cdot 2$ & $3 \cdot 4$ & 0.4 & $1 \cdot 2$ & Rowett Research Institute \\
\hline \multirow[t]{2}{*}{ Ruminococcus albus } & $\mathrm{J} 6$ & $0 \cdot 2$ & $0 \cdot 2$ & 0 & 0 & Varel et al. (1989) \\
\hline & SY3 & 0 & $0 \cdot 1$ & 0 & 0 & Varel et al. (1989) \\
\hline \multirow{2}{*}{ Ruminococcus flavefaciens } & FD1 & $1 \cdot 1$ & $6 \cdot 6$ & 0 & 0 & NCFB 2215 \\
\hline & 007 & $2 \cdot 2$ & 1.5 & 0 & 0 & Stewart et al. (1990) \\
\hline \multirow[t]{2}{*}{ Selenomonas ruminantium } & $\mathrm{Z108}$ & 2.9 & $0 \cdot 1$ & 0 & 0 & Flint \& Bisset (1990) \\
\hline & JW2 & $4 \cdot 2$ & 0 & 0 & 0 & Wallace \& Brammall (1985) \\
\hline \multirow[t]{2}{*}{ Streptococcus bovis } & $\mathrm{C} 277$ & $2 \cdot 5$ & 0.9 & $0 \cdot 1$ & $4 \cdot 3$ & Wallace \& Brammall (1985) \\
\hline & ES1 & $1 \cdot 7$ & 0.2 & $0 \cdot 3$ & $4 \cdot 1$ & Rowett Research Institute \\
\hline \multirow{2}{*}{ Veillonella parvula } & L59 & 0 & 0.1 & 0 & 0 & Rowett Research Institute \\
\hline & 692 & 0 & 0 & $0 \cdot 1$ & 0 & Rowett Research Institute \\
\hline
\end{tabular}

Incubation procedure. A portion $(0.6 \mathrm{ml})$ of bacterial suspension was added to $0.2 \mathrm{ml}$ peptide substrate $(1 \mathrm{mM})$ and incubated at $39^{\circ} \mathrm{C}$ under $\mathrm{CO}_{2}$. Alanine peptides, alanine-p-nitroanilides (pNA) and $\mathrm{N}$-Acalanine peptides were dissolved in $25 \mathrm{~mm}$-potassium phosphate buffer. $\mathrm{N}$-Ac-Ala 3 -pNA was dissolved in $100 \%$ dimethyl sulphoxide. The reaction was stopped by the addition of $0.2 \mathrm{ml} 1.25 \mathrm{M}$-orthophosphoric acid. Peptide-4-methoxy-2-naphthylamides (peptide-MNAs) were dissolved in ethanol and then mixed with $0.15 \mathrm{M}$-sodium acetate buffer, $\mathrm{pH} 5 \cdot 5$, to final concentrations of between 1 and $4 \%(\mathrm{v} / \mathrm{v})$ ethanol and 1 mM-peptide-MNA. Parallel incubations were done with 4-methoxy2-naphthylamine and ethanol. Reactions were stopped by the addition of $0.2 \mathrm{ml} 25 \%(\mathrm{w} / \mathrm{v})$ trichloroacetic acid. Acid-treated samples were stored at $-20^{\circ} \mathrm{C}$ for later analysis.

In experiments to determine the influence of PMSF, the initial concentration of $\mathrm{Ala}_{5}$ was $0.313 \mathrm{~mm}$ and the incubation time was $60 \mathrm{~min}$, except for strained rumen fluid for which the incubation time was $10 \mathrm{~min}$. The strained rumen fluid was obtained from a sheep receiving $67 \%$ grass hay and $33 \%$ concentrate diet (Whitelaw et al., 1983). PMSF was added in a $20 \%(\mathrm{v} / \mathrm{v})$ ethanol solution, giving a final ethanol concentration of $2.5 \%$ in the assay volume of $0.8 \mathrm{ml}$. The reaction was stopped by adding $0.2 \mathrm{ml} 1.25$ M-orthophosphoric acid.

The concentrations of dimethyl sulphoxide and ethanol used in these incubations had no influence on the rate of breakdown of $\mathrm{Ala}_{5}$.
Analysis of peptide substrates and products. Supernatants from phosphoric-acid-treated samples were analysed for substrates and products by HPLC. The samples were thawed, centrifuged and filtered as described previously (Wallace \& McKain, 1989). The HPLC apparatus was a Spectra-Physics system fitted with a Spherisorb ODS 2 ( $5 \mu \mathrm{m}, \mathrm{C} 18$; FSA Chromatography) column $(250$ by $4.6 \mathrm{~mm})$ and a $20 \mu \mathrm{lloop}$. The pump rate was $1.5 \mathrm{ml} \mathrm{min}^{-1}$ and the detector was set at $206 \mathrm{~nm}$. The eluant used for the analysis of the alanine oligopeptides was a mixture comprising $80 \%$ (v/v) $30 \mathrm{~mm}$-orthophosphoric acid plus 5 mm-heptane sulphonic acid (HSA) and $20 \%(\mathrm{v} / \mathrm{v})$ methanol. The alanine-pNAs were eluted using $70 \%$ (v/v) 30 mM-orthophosphoric acid and $30 \%(\mathrm{v} / \mathrm{v})$ methanol, the $\mathrm{N}$-Ac-alanine peptides were eluted using $100 \% 30 \mathrm{~mm}$-orthophosphoric acid plus $5 \mathrm{~mm}$-HSA, and $\mathrm{N}$-Ac$\mathrm{Ala}_{3}$-pNA was eluted with $60 \%$ (v/v) 30 mm-orthophosphoric acid and $40 \%(v / v)$ methanol. All samples analysed by HPLC were done in duplicate and the results were quantified by comparison with the peak area obtained when the peptide was added to rumen fluid containing 0.25 M-orthophosphoric acid. Previous experiments had shown the relationship between peak area and peptide concentration to be linear. The release of MNA from the peptide-MNA substrates was measured by its fluorescence as described previously (Wallace \& McKain, 1989). Protein was determined with the Folin reagent by the method of Herbert et al. (1971) with bovine serum albumin as the standard. 
Chemicals. HPLC-grade methanol and HSA were obtained from FSA Laboratory Supplies. Analytical-grade orthophosphoric acid was obtained from BDH. Alanine peptides, alanine-pNAs, $\mathrm{N}$-Ac-alanine peptides, $N$-Ac-Ala 3 -pNA, LysAla-MNA ArgArg-MNA, GlyProMNA, MNA and PMSF were obtained from Sigma. GlyArg-MNA, LeuVal-MNA amd Leu-MNA were obtained from Bachem.

\section{Results}

Twenty-nine strains of 14 species of predominant rumen bacteria were screened for their ability to hydrolyse $\mathrm{Ala}_{2}$, $\mathrm{Ala}_{5}$, GlyArg-MNA and Leu-MNA (Table 1). Several species were active against $\mathrm{Ala}_{2}$, with very high activities being shown by both strains of $M$. elsdenii, one strain of $B a$. ruminicola (223/M2/7) and one strain of Fibrobacter succinogenes (BL2). Fewer species were active against $\mathrm{Ala}_{5}$, with the highest activities being shown by all strains of $B a$. ruminicola, one strain of $B u$. fibrisolvens (SH13), both strains of L. multipara, both strains of $R b$. amylophilus and one strain of $R c$. flavefaciens (FD1).

HPLC analysis of $\mathrm{Ala}_{5}$ disappearance from the culture medium also revealed which alanine peptides were formed as products of the hydrolysis. Ala $_{4}$ was the major product from $L$. multipara D15d, Rc. flavefaciens FD1 and $R b$. amylophilus WP91. The Ba. ruminicola strains and Bu. fibrisolvens $\mathrm{SH} 13$ hydrolysed $\mathrm{Ala}_{5}$ to $\mathrm{Ala}_{3}$ and $\mathrm{Ala}_{2}$, with little $\mathrm{Ala}_{4}$ being produced. PMSF had little influence on $\mathrm{Ala}_{5}$ breakdown by rumen fluid or by individual bacterial species, except for slight inhibition (22\%) with Bu. fibrisolvens (Table 2).

Exceptionally high leucine arylamidase activity was shown by Str. bovis, with lower activity being associated with $R b$. amylophilus (Table 1). However, only $B a$. ruminicola showed substantial activity against GlyArgMNA.

Ba. ruminicola M384 and Bu. fibrisolvens SH13 were investigated further to determine their activities against a range of alanine peptide substrates (Table 3). The two species showed similar rates of hydrolysis with the alanine oligomers and similar low activity with the $\mathrm{N}$-acetylated alanine peptides. However, $\mathrm{Ba}$. ruminicola had a much higher activity against alanine-pNAs thar $B$ B. fibrisolvens.

Further differences were seen when the disappearance of substrates and accumulation of intermediates from alanine peptides and alanine peptide-pNAs were measured during the incubations. As before, $\mathrm{Ala}_{3}, \mathrm{Ala}_{4}$ and $\mathrm{Ala}_{5}$ were hydrolysed at similar rates by $B a$. ruminicola (Fig. 1) and $\mathrm{Ala}_{4}$ was more slowly hydrolysed relative to $\mathrm{Ala}_{3}$ and $\mathrm{Ala}_{5}$ by $\mathrm{Bu}$. fibrisolvens (Fig. 2). Concentrations of products from $\mathrm{Ala}_{4}$ were small with $B u$. fibrisolvens, but otherwise the patterns of products appeared similar for $B a$. ruminicola and Bu. fibrisolvens.
Table 2. Influence of PMSF on Ala ${ }_{5}$ hydrolysis

The results are means of duplicate incubations in the absence or presence of $125 \mu \mathrm{g}$ PMSF ml-1.

\begin{tabular}{lcc}
\hline & \multicolumn{2}{c}{ Ala $_{5}$ hydrolysis } \\
& [nmol min $^{-1}$ (mg protein) & \\
\cline { 2 - 3 } \multicolumn{1}{c}{ Species } & - PMSF & + PMSF \\
\hline Ba. ruminicola M384 & $2 \cdot 9$ & $3 \cdot 3$ \\
Bu. fibrisolvens SH13 & $5 \cdot 4$ & $4 \cdot 2$ \\
L. multipara D15d & $1 \cdot 7$ & $1 \cdot 7$ \\
Rc. flavefaciens FD1 & $3 \cdot 3$ & $3 \cdot 0$ \\
Strained rumen fluid & $4 \cdot 2$ & $4 \cdot 0$ \\
\hline \hline
\end{tabular}

Table 3. Activity of Ba. ruminicola and Bu. fibrisolvens against a range of Ala peptides

The results are means and standard errors of the initial rate of peptide hydrolysis measured in duplicate from four samples.

\begin{tabular}{|c|c|c|c|c|}
\hline \multirow{3}{*}{$\begin{array}{l}\text { Peptide } \\
\text { substrate }\end{array}$} & \multicolumn{4}{|c|}{$\begin{array}{c}\text { Rate of hydrolysis } \\
{\left[\text { nmol } \min ^{-1}(\text { mg protein })^{-1}\right]}\end{array}$} \\
\hline & \multicolumn{2}{|c|}{$\begin{array}{l}\text { Ba. ruminicola } \\
\text { M384 }\end{array}$} & \multicolumn{2}{|c|}{$\begin{array}{l}\text { Bu. fibrisolvens } \\
\text { SH13 }\end{array}$} \\
\hline & Mean & SE & Mean & SE \\
\hline $\mathrm{Ala}_{2}$ & $4 \cdot 34$ & 0.29 & $4 \cdot 20$ & 0.48 \\
\hline $\mathrm{Ala}_{3}$ & $4 \cdot 40$ & 0.64 & $5 \cdot 18$ & $0 \cdot 27$ \\
\hline $\mathrm{Ala}_{4}$ & $4 \cdot 70$ & $1 \cdot 36$ & $2 \cdot 11$ & 0.32 \\
\hline $\mathrm{Ala}_{5}$ & $3 \cdot 74$ & $0 \cdot 85$ & 3.96 & $0 \cdot 37$ \\
\hline Ala-pNA & $7 \cdot 48$ & 0.50 & 0.73 & 0.40 \\
\hline $\mathrm{Ala}_{2}$-pNA & $11 \cdot 26$ & $0 \cdot 18$ & $3 \cdot 70$ & 0.36 \\
\hline $\mathrm{Ala}_{3}$-pNA & $21 \cdot 57$ & 1.99 & $1 \cdot 28$ & $0 \cdot 11$ \\
\hline$N$-Ac-Ala 3 & 0.79 & $0 \cdot 11$ & $0 \cdot 17$ & $0 \cdot 15$ \\
\hline $\mathrm{N}$-Ac-Ala 4 & $1 \cdot 54$ & 0.26 & 0.46 & 0.17 \\
\hline$N$-Ac-Ala - pNA & 0.70 & 0.12 & 0.04 & 0.04 \\
\hline
\end{tabular}

$B a$. ruminicola hydrolysed $\mathrm{Ala}_{2}-\mathrm{pNA}$ rapidly with almost no Ala-pNA formed (Fig. 3). In contrast, the breakdown of $\mathrm{Ala}_{2}$-pNA by Bu. fibrisolvens was slower and Ala-pNA was formed (Fig. 4). When $\mathrm{Ala}_{3}$-pNA was used as the substrate, $B a$. ruminicola produced significant amounts of Ala-pNA with very little $\mathrm{Ala}_{2}$-pNA, whereas $B$. fibrisolvens showed only low activity against $\mathrm{Ala}_{3}$-pNA, with very small amounts of both intermediates formed.

When dipeptide-MNAs were used as the substrates $B u$. fibrisolvens showed no activity, but $B a$. ruminicola hydrolysed GlyArg-MNA, LysAla-MNA and ArgArgMNA rapidly and had lower activity against LeuValMNA and GlyPro-MNA (Table 4). The release of MNA was linear over the first 10-20 min with GlyArg-MNA, LysAla-MNA and ArgArg-MNA, the first 30 min with GlyPro-MNA and $60 \mathrm{~min}$ with LeuVal-MNA (results not shown). 

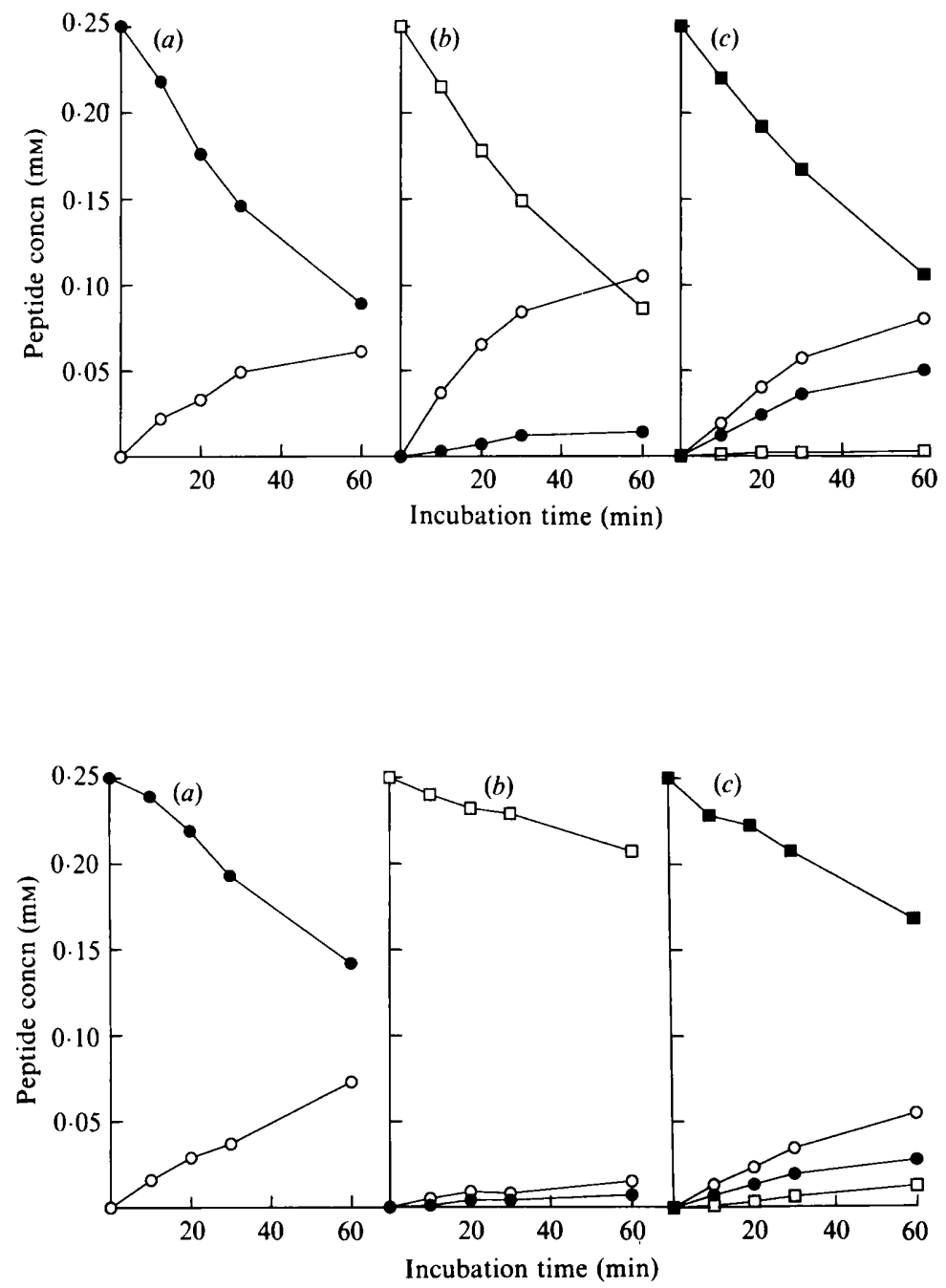

Fig. 1. Hydrolysis of (a) $\mathrm{Ala}_{3},(b) \mathrm{Ala}_{4}$ and (c) $\mathrm{Ala}_{5}$ by Ba. ruminicola M384. Concentrations of $\mathrm{Ala}_{2}(\mathrm{O}), \mathrm{Ala}_{3}(\bullet), \mathrm{Ala}_{4}$ $(\square)$ and $\mathrm{Ala}_{5}(\square)$ were measured by HPLC.
Fig. 2. Hydrolysis of (a) $\mathrm{Ala}_{3}$, (b) $\mathrm{Ala}_{4}$ and (c) $\mathrm{Ala}_{5}$ by Bu. fibrisolvens $\mathrm{SH}$ 13. Concentrations of $\mathrm{Ala}_{2}(\mathrm{O}), \mathrm{Ala}_{3}(\bullet), \mathrm{Ala}_{4}$ $(\square)$ and $\mathrm{Ala}_{5}$ (ם) were measured by HPLC.

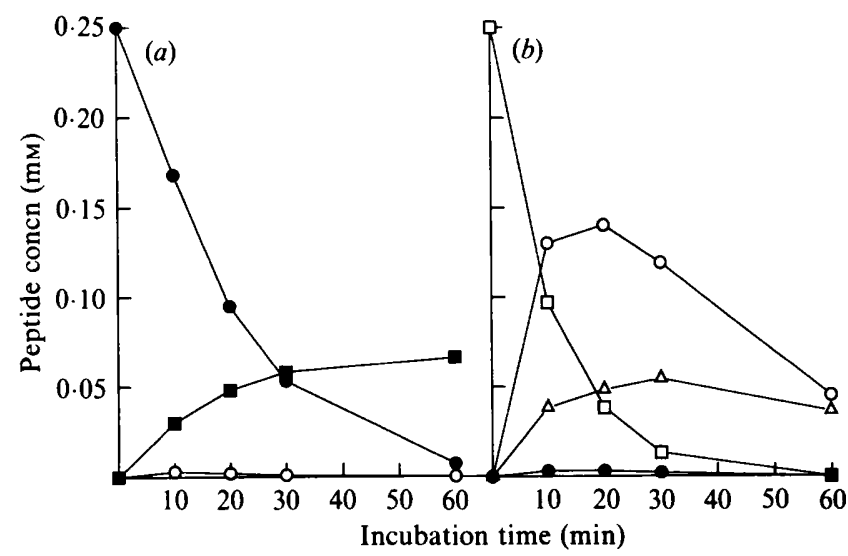

Fig. 3. Hydrolysis of (a) $\mathrm{Ala}_{2}$-pNA and (b) $\mathrm{Ala}_{3}$-pNA by Ba. ruminicola M384. Concentrations of Ala-pNA (O), Ala 2 -pNA (•), Ala $_{3}-$ pNA ( $(\square)$, $\operatorname{Ala}_{2}(\triangle)$ and $p$-nitroaniline ( $\square$ ) were measured by HPLC. Ala ${ }_{2}$ was not determined in $(a)$. No free $p$-nitroaniline was detected in $(b)$.

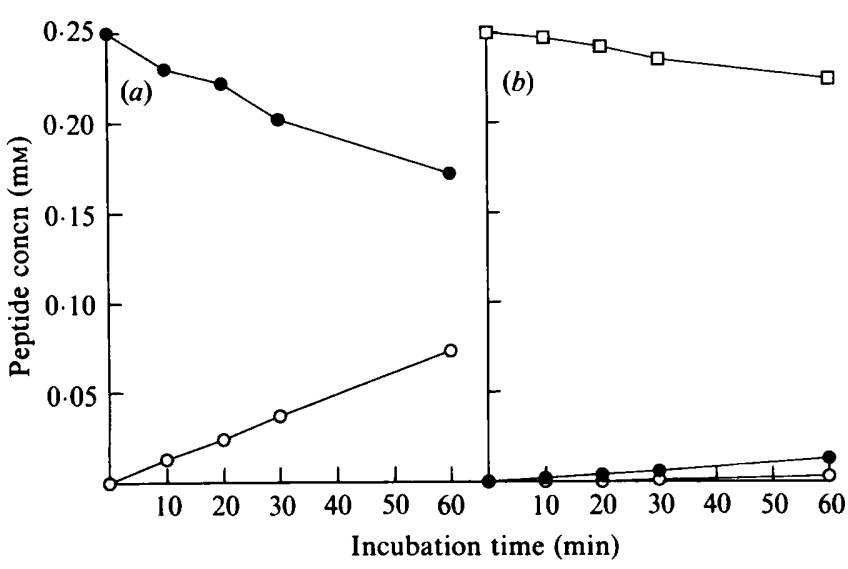

Fig. 4. Hydrolysis of (a) $\mathrm{Ala}_{2}-\mathrm{pNA}$ and (b) $\mathrm{Ala}_{3}$-pNA by $B$. fibrisolvens SH13. Concentrations of Ala-pNA (O), Ala $a_{2}$-pNA ( $(\bullet)$ and $\mathrm{Ala}_{3}$-pNA ( $\square$ ) were measured by HPLC. 
Table 4. Hydrolysis of dipeptide-MNA substrates by $B$ a. ruminicola $M 384$

The results are means and standard errors of four observations.

\begin{tabular}{|c|c|c|}
\hline \multirow[b]{2}{*}{ Substrate } & \multicolumn{2}{|c|}{$\begin{array}{c}\text { Rate of MNA release } \\
{\left[\text { nmol } \min ^{-1}(\mathrm{mg} \text { protein })^{-1}\right]}\end{array}$} \\
\hline & Mean & $\mathbf{S E}$ \\
\hline GlyArg-MNA & 19.82 & 1.94 \\
\hline LysAla-MNA & $11 \cdot 28$ & 0.67 \\
\hline ArgArg-MNA & 15.08 & 1.32 \\
\hline LeuVal-MNA & 2.05 & $0 \cdot 28$ \\
\hline GlyPro-MNA & $5 \cdot 10$ & 0.91 \\
\hline
\end{tabular}

\section{Discussion}

Previous experiments (Newbold et al., 1989; Wallace et $a l ., 1990 a, b)$ identified ciliate protozoa as having a higher dipeptidase activity than bacteria in the mixed rumen population, with protozoal specific activity against $\mathrm{Ala}_{2}$ being more than twice that of mixed bacteria. From the present survey it is clear that several species of bacteria, notably $M$. elsdenii, individually possess high dipeptidase activity. Under normal circumstances where the rumen is colonized by ciliate protozoa, these bacteria may be suppressed. However, it is presumably these species which proliferated to replace the dipeptidase activity of protozoa when they were absent from the ecosystem (Wallace et al., 1987).

The main peptidase activity of the rumen is otherwise bacterial in origin (Newbold et al., 1989; Wallace et al., $1990 a, b$ ). Several of the species screened in this survey hydrolysed $\mathrm{Ala}_{5}$, but only $\mathrm{Bu}$. fibrisolvens and $\mathrm{Ba}$. ruminicola did so in a manner similar to rumen fluid, in which the immediate products were the di- and tripeptides with little or no tetrapeptide formed (Wallace \& McKain, 1989; Wallace et al., 1990a,b). Other species which have a high leucine aminopeptidase activity, particularly $R b$. amylophilus and, as noted previously (Russell \& Robinson, 1984; Wallace \& Brammall, 1985), Str. bovis, must play a relatively minor role in peptide breakdown in vivo. The hydrolysis of $\mathrm{Ala}_{3}, \mathrm{Ala}_{4}$ and $\mathrm{Ala}_{3}$-pNA by these strains was, as with rumen fluid (Wallace et al., 1990a, b), effectively prevented by the presence of an acetyl group at the $\mathrm{N}$-terminus. It should be noted here that the peptidase activities were measured in stationary phase cultures. Although the enzyme specificity is unlikely to be different in exponential phase cells, it is possible that marked changes in specific activity might occur.

When the activities of $B a$. ruminicola and $B u$. fibrisolvens against peptide arylamide substrates were compared, major differences between the two species and between the activity of $B u$. fibrisolvens and that of rumen fluid became apparent. $B a$. ruminicola and rumen fluid both hydrolysed GlyArg-MNA, LysAla-MNA, ArgArg-MNA and GlyPro-MNA (Table 4; Wallace \& McKain, 1989), which are diagnostic substrates for the dipeptidyl peptidases types I to IV (McDonald \& Barrett, 1986; McDonald \& Schwabe, 1977). Type I activity was highest both in rumen fluid and in $B a$. ruminicola. Bu. fibrisolvens had no activity against dipeptidyl peptidase substrates. Further, Ba. ruminicola hydrolysed $\mathrm{Ala}_{2}$-pNA without Ala-pNA being formed, as would be expected from a dipeptidyl peptidase mechanism, whereas Ala-pNA was the main product with $B$. fibrisolvens.

The enzymic mechanism(s) responsible for the peptide hydrolysis by $\mathrm{Bu}$. fibrisolvens remains unclear, therefore. As hydrolysis of $\mathrm{Ala}_{3}$ and $\mathrm{Ala}_{4}$ was blocked by an Nterminal acetyl group, an aminopeptidase activity is implied. However, blocking the C-terminus also decreased the rate of hydrolysis of alanine peptides. Since PMSF, which inhibits the main proteinase activities of Bu. fibrisolvens (Wallace \& Brammall, 1985; Strydom et al., 1986), had little effect on Ala $_{5}$ hydrolysis, and since $\mathrm{N}$-Ac-Ala ${ }_{3}$-pNA was not hydrolysed, it seems unlikely that endopeptidase activity was responsible for $\mathrm{Ala}_{5}$ breakdown.

As noted previously (Wallace \& McKain, 1989), reports of dipeptidyl peptidases in bacteria are rare, and at present bacterial enzymes similar to type I dipeptidyl peptidases have not been identified. However, Bacteroides fragilis has cell-associated arylamidase activities which are active against ValAla-pNA and GlyPro-pNA (Gibson \& Macfarlane, 1988) and which could include a dipeptidyl peptidase. This can only be confirmed when the immediate products of hydrolysis have been analysed.

Ba. ruminicola is one of the principal ammoniaproducing bacteria in the rumen (Bladen et al., 1961). We conclude that, unlike the other bacteria screened in this survey, it has a peptidase activity similar in specificity to the main activity present in rumen fluid. Its specific activities against $\mathrm{Ala}_{3}, \mathrm{Ala}_{4}$ and $\mathrm{Ala}_{5}$ in pure culture $\left[4.4,4.7\right.$ and $2.1-11.1 \mathrm{nmol}$ hydrolysed $\mathrm{min}^{-1}$ (mg protein) ${ }^{-1}$, respectively] compare with very similar specific activities in rumen fluid [7.3, 5.8 and up to $12.8 \mathrm{nmol} \mathrm{min}{ }^{-1}$ (mg protein) ${ }^{-1}$; Wallace \& McKain, 1989; Wallace et al., 1990a]. Similarly, the activity of $B a$. ruminicola towards GlyArg-MNA was $2 \cdot 5-10 \cdot 1 \mathrm{nmol}$

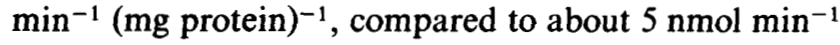
(mg protein) $)^{-1}$ in rumen fluid (Wallace \& McKain, 1989). Thus, the predominance of $B a$. ruminicola in peptide hydrolysis in vivo must depend largely on its high population size. Van Gylswyk (1990) estimated that $B a$. ruminicola comprised $60 \cdot 1 \%$ of the bacterial population 
in dairy cows fed grass silage. While such a high proportion may not be typical, $B a$. ruminicola would normally be expected to be a significant member of the rumen bacterial population (Stewart \& Bryant, 1988).

Much of the work that has been done on peptide metabolism in $\mathrm{Ba}$. ruminicola has tended to emphasize the anabolic and growth-stimulatory role of peptides in this organism (Pittman \& Bryant, 1964; Pittman et al., 1967; Cotta \& Russell, 1982; Russell, 1983). Experiments on its catabolic role, such as the chemostat studies of Russell (1983), should be extended to determine where (catabolic) peptidase activity is located, how it is regulated and if it can be inhibited. It may then be possible to devise ways of slowing peptide breakdown in the rumen, to the nutritional benefit of the host animal.

We thank Nicola Watt and Sylvia Duncan for supplying bacterial cultures, and $\mathrm{Dr} \mathrm{H}$. J. Flint for discussion and constructive criticism of the manuscript.

\section{References}

Bladen, H. A., Bryant, M. P. \& Doetsch, R. N. (1961). A study of bacterial species from the rumen which produce ammonia from protein hydrolyzate. Applied Microbiology 9, 175-180.

Cotta, M. A. \& Russell, J. B. (1982). Effect of peptides and amino acids on efficiency of rumen bacterial protein synthesis in continuous culture. Journal of Dairy Science 65, 226-234.

FLINT, H. J. \& BiSSET, J. (1990). Genetic diversity in Selenomonas ruminantium isolated from the rumen. FEMS Microbiology Ecology 73, 351-360.

Flint, H. J. \& StewarT, C. S. (1987). Antibiotic resistance patterns and plasmids of ruminal strains of Bacteroides ruminicola and Bacteroides multiacidus. Applied Microbiology and Biotechnology 26, 450-455.

Flint, H. J., Thomson, A. M. \& Bisset, J. (1988). Plasmid-associated transfer of tetracycline resistance in Bacteroides ruminicola. Applied and Environmental Microbiology 54, 855-860.

Gibson, S. A. W. \& MacFarlane, G. T. (1988). Studies on the proteolytic activity of Bacteroides fragilis. Journal of General Microbiology 134, 19-27.

Herbert, D., Phipps, P. J. \& Strange, R. E. (1971). Chemical analysis of microbial cells. Methods in Microbiology 5B, 209-344.

Hobson, P. N. (1969). Rumen bacteria. Methods in Microbiology 3B, 133-149.

LENG, R. A. \& Nolan, J. V. (1984). Nitrogen metabolism in the rumen. Journal of Dairy Science 70, 1072-1089.

MCDonald, J. K. \& BARReTt, A. J. (1986). Mammalian Proteases: a Glossary and Bibliography, vol. 2. Exopeptidases. New York: Academic Press.

MCDONALD, J. K. \& SCHWABE, C. (1977). Intracellular exopeptidases. In Proteinases in Mammalian Cells and Tissues, pp. 311-391. Edited by A. J. Barrett. Amsterdam: Elsevier/North Holland Biomedical Press.

Newbold, C. J., McKain, N. \& Wallace, R. J. (1989). The role of protozoa in ruminal peptide metabolism. In Biochemistry and
Molecular Biology of "Anaerobic" Protozoa, pp. 42-55. Edited by D. Lloyd, G. H. Coombs \& T. A. Paget. London: Harwood Academic Publishers.

Pittman, K. A. \& Bryant, M. P. (1964). Peptides and other nitrogen sources for growth of Bacteroides ruminicola. Journal of Bacteriology 88, 401-410.

Pittman, K. A., Lakshmanan, S. \& Bryant, M. P. (1967). Oligopeptide uptake by Bacteroides ruminicola. Journal of Bacteriology 93, 1499-1508.

RUSSELL, J. B. (1983). Fermentation of peptides by Bacteroides ruminicola $\mathrm{B}_{1} 4$. Applied and Environmental Microbiology 45, 15661574.

Russell, J. B. \& Robinson, P. H. (1984). Compositions and characteristics of strains of Streptococcus bovis. Journal of Dairy Science 67, 1525-1531.

Stewart, C. S. \& Bryant, M. P. (1988). The rumen bacteria. In The Rumen Microbial Ecosystem, pp. 21-75. Edited by P. N. Hobson. London: Elsevier Applied Science.

Stewart, C. S., Duncan, S. H., McPherson, C. A., Richardson, A. J. \& FLINT, H. J. (1990). The implications of the loss and regain of cotton-degrading activity for the degradation of straw by Ruminococcus albus strain 007. Journal of Applied Bacteriology 68, 349-356.

STRYDOM, E., MACKIE, R. I. \& WoOdS, D. R. (1986). Detection and characterisation of extracellular proteases in Butyrivibrio fibrisolvens H17c. Applied Microbiology and Biotechnology 24, 214-217.

VAN GYLSWYK, N. O. (1990). Enumeration and presumptive identification of some functional groups of bacteria in the rumen of dairy cows fed grass silage-based diets. FEMS Microbiology Ecology 73, $243-254$.

VAREL, V., RichardSON, A. J. \& SteWART, C. S. (1989). Degradation of barley straw, ryegrass, and alfalfa cell walls by Clostridium longisporum and Ruminococcus albus. Applied and Environmental Microbiology 55, 3080-3084.

WALLACE, R. J. (1988). Ecology of rumen microorganisms: protein use. In Aspects of Digestive Physiology in Ruminants, pp. 99-122. Edited by A. Dobson \& M. Dobson. Ithaca: Cornell University Press.

Wallace, R. J. \& Brammall, M. L. (1985). The role of different species of bacteria in the hydrolysis of protein in the rumen. Journal of General Microbiology 131, 821-832.

Wallace, R. J. \& CotTA, M. A. (1988). Metabolism of nitrogencontaining compounds. In The Rumen Microbial Ecosystem, pp. $217-$ 249. Edited by P. N. Hobson. London: Elsevier Applied Science.

Wallace, R. J. \& McKaIN, N. (1989). Analysis of peptide metabolism by ruminal microorganisms. Applied and Environmental Microbiology 55, 2372-2376.

Wallace, R. J., Broderick, G. A. \& Brammall, M. L. (1987). Microbial protein and peptide metabolism in rumen fluid from faunated and ciliate-free sheep. British Journal of Nutrition 58, 87-93.

Wallace, R. J., MCKaIN, N. \& NewBold, C. J. (1990a). Metabolism of small peptides in rumen fluid. Accumulation of intermediates during hydrolysis of alanine oligomers, and comparison of peptidolytic activities of bacteria and protozoa. Journal of the Science of Food and Agriculture 50, 191-199.

Wallace, R. J., Newbold, C. J. \& McKain, N. (1990b). Patterns of peptide metabolism by rumen microorganisms. In The Rumen Ecosystem. The Microbial Metabolism and its Regulation, pp. 43-50. Edited by S. Hoshino, R. Onodera, H. Minato \& H. Itabashi. Tokyo: Japan Scientific Societies Press.

Whitelaw, F. G., Bruce, L. A., Eadie, J. M. \& Shand, W. J. (1983). 2-Aminoethylphosphonic acid concentrations in some rumen ciliate protozoa. Applied and Environmental Microbiology 46, 951-953. 